\title{
Sustainability of Teredo navalis $L$ and Environmental Management Strategies in the Pandemic Era COVID-19
}

\author{
Yumima Sinyo ${ }^{1,2^{*}}$, Sutrisno Anggoro ${ }^{3}$, Tri Retnaningsih Soeprobowati ${ }^{1,4}$ \\ ${ }^{1}$ School of Postgraduate Studies, Diponegoro University, Semarang - Indonesia \\ ${ }^{2}$ Biology Education Study Program, Department of Mathematics and Natural Sciences, Khairun \\ University, Ternate - Indonesia \\ ${ }^{3}$ Faculty of Fisheries and Marine Sciences, Diponegoro University, Semarang - Indonesia \\ ${ }^{4}$ Department of Biology, Faculty of Science and Mathematics, Diponegoro University, Semarang - \\ Indonesia
}

\begin{abstract}
The Wailukum Mangrove Ecosystem requires a community based environmental management strategy. The purpose of this study was to analyze the characteristics of mangrove roots and stems in medium tide zones, the dominance index of Teredo navalis $L$ and environmental management strategies in the era of the COVID-19 pandemic. This type of research is a case study. The research location is divided into two points, namely in the North and South. Sampling using the line transect method. Root and stem samples were observed using the quadratic method. The results of this study found that there are three types of mangroves that live in the medium tide zone, namely Rhizophora mucronata (Lamk.) Rhizophora apiculata and Rhizophora stylosa Griff. Characteristics of roots and stems have gaps and brittle easily. The dominance index of Teredo navalis $L$ on the roots and stems is in the low category with the index range 0.01-0.62. Strategies that need to be used for environmental management of mangroves in Wailukum, East Halmahera Regency, are to open employment opportunities for the community, organize socialization and training of silvofishery systems for workers, make regulations to control community-based mangrove use and monitor violations of mangrove management.
\end{abstract}

Keywords: Sustainability of Teredo navalis $L$, environmental management strategies in the Pandemic Era COVID-19

\footnotetext{
* Corresponding author: yumima@unkhair.ac.id
} 


\section{Introduction}

Wailukum is one of the coastal areas dominated by mangrove forests. Administratively, it is included in the District of Maba City, East Halmahera Regency, North Maluku Province. The geographical location of Maba City is at Latitude 0 037'25 "- 0 055'10" North Latitude and Longitude 127 057'45 "- 128'27'20" East Longitude. The boundaries of Maba City in the north are bordered by Maba City, the southern part is Central Halmahera Regency, the west side is South Wasile District and the east is bordered by south Maba City. This area is known to have a coastal ecosystem, one of which is the mangrove ecosystem. The existence of these ecosystems provides opportunities for all types of aquatic biota, especially molluscs to live in their habitat [1].

Mangrove forests have an ecological function in preventing erosion and coastal abrasion as well as sediment trapping [2], also as a food producer for biota and humans [3]. The area is always in undated by sea water and fresh water flows so that it continues to grow, develop and experience succession that brings changes to its natural habitats [4]. One type of mangrove that grows in soil that is always in undated by brackish water is Rhizophora $s p$ [5]. Because it is always in undated with water, the mangrove ecosystem has extreme physical environmental factors such as salinity, temperature and the type of muddy substrate [6].

The Wailukum mangrove forest area has a high biodiversity of marine life. This provides opportunities for aquatic biota to carry out important activities in adapting, protecting, developing themselves and maintaining their life in their habitat [7].

Mollusca Teredo navalis Linnaeus 1758 is a group of marine biota which is also known as shipworm, which has prospects in the ecological balance of mangroves. Mangroves that grow in the medium tide zone have their own characteristics such as being easily brittle as a form of adaptation to the environmental conditions where they grow and are influenced by the tides of sea water, so that they can contribute to life for Teredo navalis $L$ and have the potential to be used as a place to live by animals Teredo navalis L. [8]. Each type of mangrove has unique morphological characters such as the shape of roots and stems that have gaps. Teredo navalis $L$ acts as the main consumer of mangrove roots and stems, so it plays its role through the activity of destroying wood using its shell on its head which functions as a drill assisted by cellulose and nitrogen binding bacteria [9]. Activity Teredo navalis $L$ is influenced by environmental temperature so that it can increasing the export of nutrients from mangrove ecosystems to other coastal zones [10]. In the summer the spread of $T$. navalis $L$ occurs very rapidly. This can be proven through the formation of many boreholes or gaps in all types of mangrove wood [9,11]. Mangrove forests play an important role in river flow systems and coastal waters which function as a buffer and biofilter and are tolerant of pollution sources because they have the ability to absorb pollutants [12].

Management of the coastal environment needs to be carried out by various parties to overcome problems and disasters that occur and attack biota and humans. Currently the world is facing environmental health problems, namely the outbreak of the corona virus or COVID-19. North Maluku Province, since March 2, 2020, the COVID-19 case began to become epidemic in Ternate City. Since then it has started to increase until the end of this June. Date from the COVID-19 task force processed by kieraha.com showed that the number of people in June 2020 increased to 266, this illustrates the rapid spread of cases from case date in the previous months which only experienced an increase of 19 to 79 new cases. Deputy head of the Representative Epidemiology Association for North Maluku Province, Isya Tauda, stated that since the relaxation was imposed on June 5, new positive 
cases of COVID-19 have increased by more than 100 percent. This shows that the increase in the number of positive cases is increasing and the confirmed area has expanded to district City. _On June 14, 2020, there were 8 more Covid-19 patients, 7 of whom came from Ternate City and 1 person from East Halmahera district so that the number of confirmed positive cases of COVID-19 from 302 people increased to 310 people. Based on the date, this case increase shows that environmental health is experiencing problems and has a profound impact on the social and economy of the local community.

East Halmahera Regency, North Maluku Province is an area prone to natural disasters such as earthquakes and forest damage due to mining activities, land conversion, flooding, and landslides. The main problem that occurs in mangrove forest areas is land use change and coastal pollution due to mining waste that is dumped around the area. Therefore it needs management efforts and requires active participation of the government and society in increasing synergy to anticipate environmental problems. For this reason, it is necessary to have a study related to a sustainable management strategy and improvement of the natural environment (ecology) of mangroves. This research was conducted with the aim of analyzing the characteristics of mangrove roots and stems in the medium tide zone, the dominance of Teredo navalis $L$ in habitats and environmental management strategies in the Covid19 pandemic era. It is hoped that the results of this study will become a material contribution for the local government to the sustainability of Teredo navalis $L$ in the Wailukum mangrove ecosystem and an environmentally friendly coastal area management strategy.

\section{Methods}

\subsection{Research Time and Place}

Study was conducted from March to May 2019. Research site for mangrove forest in Wailukum, East Halmahera Regency. This type of research is a case study, using a purposive sampling method, namely determining the sampling point based on the surrounding environment. The research area is divided into two locations, namely Location I in the North and Location II in the South. Characteristics of mangroves observed are the roots and stems that have undergone a process of maturity, are flooded and experience brittleness.

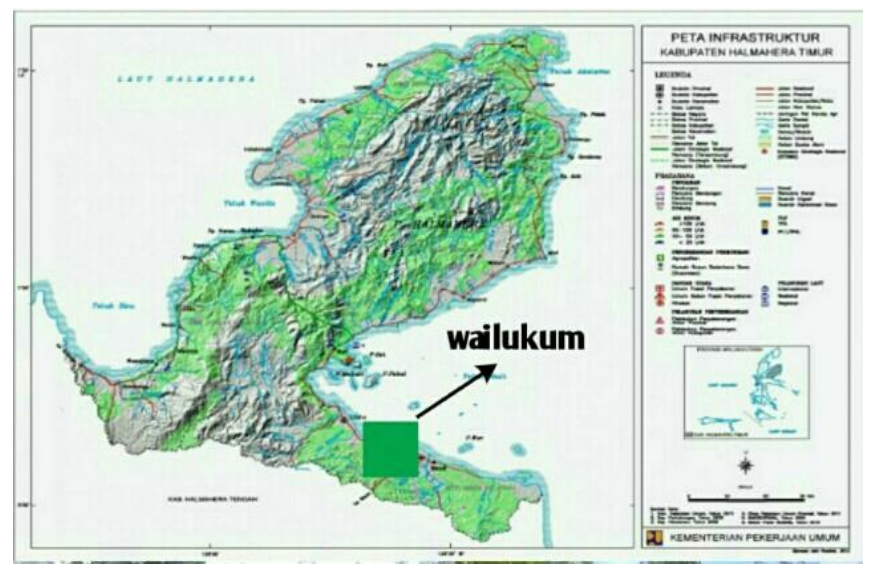

Fig. 1. Map of research location in Wailukum mangrove forest, East Halmahera District 


\subsection{Tools and Materials}

Research tools and materials used in this study are roller meters, sensor machines, swords, digital cameras, gloves, clasps, buckets, and aquades. The sampling method used a line transect with a length of 100 meters measured from the coastline of the lowest tide to the land area. Root and stem samples were observed at distances of 0-20 m, 21-40 m, 41-50 meters using the quadratic method [13]. The distribution of Teredo navalis $L$ was observed on the roots and stems found at the two observation points using the survey method. Root and stem samples were measured in size of 1 meter then cut and split. The results of observations of root, stem and samples were Teredo navalis $L$ recorded through the table. Strategy formulation is one of the methods used to obtain efforts and strategies for mangrove forest management in Wailukum Halmahera Regency.

\subsection{Date}

Analysis of the characteristics of the roots and stems of mangrove species was carried out descriptively, while the dominance of Teredo navalis $L$ analyzed using the dominance index formula from Simpson (Odum, 1993):

Information:

$$
\mathrm{D}=\square(\mathrm{ni} / \mathrm{N})^{2}
$$

$\mathrm{D}=$ Simpson dominance index

$\mathrm{ni}=$ number of individuals per species

$\mathrm{N}=$ number of individuals of all species

Dominance index can be grouped into 3 groups, namely: $0.00<\mathrm{C} \leq 0.50=$ Low, 0.50 $<\mathrm{C} \leq 0.75=$ Medium, and $0.75<\mathrm{C} \leq 1.00=$ High .

Analysis of efforts and strategies for environmental management using the SWOT approach (Strengths, Weaknesses, Opportunities, and Threats).

\section{Results and Discussion}

\subsection{Characteristics of mangroves at locations I and II}

Based on the results of the study, three types of mangroves were found in the medium tide zone of the Wailukum mangrove forest, namely from the genus Rhizophora consisting of Rhizophora mucronata (Lamk), Rhizophora apiculata and Rhizophora stylosa Griff. The characteristics of the mangroves observed in this study were the roots and stems where lived Teredo navalis $L$. Description of the characteristics of each type of mangrove found in the moderate tide zone, namely:

1. Rhizophora mucronata (Lamk.),

10-22 meters high, 30-70 cm in diameter, dark brown and black bark, horizontal slits. Supporting roots and air roots (breath) that grow from the lower part of the branch. It grows in tidal areas, always inundated by water and river mouths on a hard substrate mixed with sand, and in soil rich in humus, has a wide distribution. As a source of food for marine life (crabs and Teredo navalis $L$ ).

2. Rhizophora apiculata

Height reaches 7-25 meters. The stem diameter ranges from $30-50 \mathrm{~cm}$. The bark is dark gray and fickle. It has breath (water) roots that come out of the branch and measure 3-5 meters. It grows in soft, deep and stagnant muddy soil during normal tide and is always inundated by low tide. Being a food source for beetles, Crabs and Teredo navalis $L$.

3. Rhizophora stylosa Griff

Has more than one stem, up to 4 - 10 meters high. Has a thin, slit, gray to black bark surface. Types of root and aerial roots from under the branches measuring up to 3 
meters. habitats in tidal areas, mud, sand and rock and in water sheds. It is a type of pioneer mangrove in the coastal environment and inland mangrove areas.

The results of observations on the characteristics of the three types of mangroves indicated that almost all tree species found had a height of 7-25 meters. The morphology of the stem was found to have gaps and the skin surface varied in color because it was always changing. The vegetation is classified as a tree with a trunk diameter of $>10 \mathrm{~cm}$. The ecology of these three types of mangroves has the same growing area, namely in tidal areas and is always inundated by water, growing on a type of substrate dominated by mud, and mud mixed with sand [14]. The growth and development of mangroves is highly influenced by the environment, especially climate and adaptation factors such as the location of the delta, hydrology of sediments and turbidity of water. This greatly affects every type of mangrove that grows on the alluvial muddy substrate type in the coastal zone [15] and has a wide growing spread so that it dominates other vegetation. One of the supporting factors for the spread of mangroves is tides [16].

\subsection{Dominance of Teredo navalis $L$}

Based on the mangrove characteristics above, the observation of the dominance of Teredo navalis $L$ was carried out in two stages, namely observing the roots and stems then observing the dominance of Teredo navalis $L$. The observations found the presence of Teredo navalis $L$ both on the roots and stems, which are presented in table 1 below.

Table 1. Number of root and stem species found at locations I and II

\begin{tabular}{|l|c|c|c|c|}
\hline \multirow{2}{*}{ Mangrove species } & \multicolumn{4}{|c|}{ Number of roots and stems } \\
\cline { 2 - 5 } & \multicolumn{2}{|c|}{ Root } & \multicolumn{2}{c|}{ Stems } \\
\cline { 2 - 5 } & Location I & Location II & Location I & Location II \\
\hline Rhizophora mucronata (Lamk.) & 18 & 17 & 48 & 23 \\
\hline Rhizophora apiculata & 21 & 12 & 17 & 14 \\
\hline Rhizophora stylosa Griff & 12 & 7 & 16 & 9 \\
\hline Total & 51 & 36 & 81 & 46 \\
\hline
\end{tabular}

Based on the data in table 1, the number of roots and stems obtained from the three types of mangroves has a different number in each study location. Rhizophora Mucronata (Lamk) has a total number of roots at locations I and II is 35 and the number of roots as much as 71. Rhizophora Apiculata has a total number of roots at locations I and II , 33 and 31 stems. The total number of roots in Rhizophora stylosa Griff is 19 and a total of 25 stems. The condition of rotten roots and stems has hollow gaps and found in it the animal Teredo navalis $L$. . Mangroves that are always submerged in water undergo a faster process weathering and juveniles are occupied by locomotion [17], as shown in Figure 2 below. 


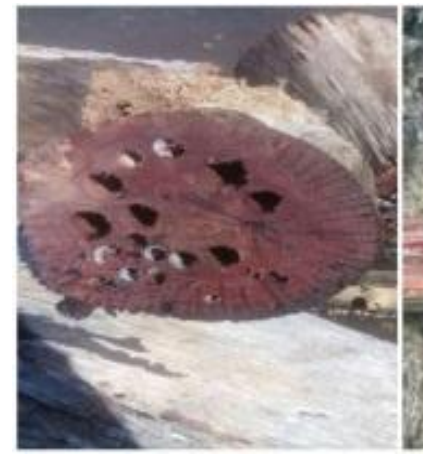

A

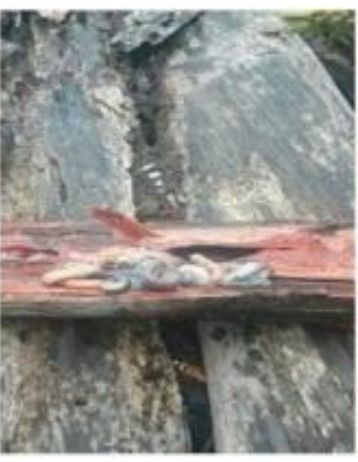

$\mathrm{B}$

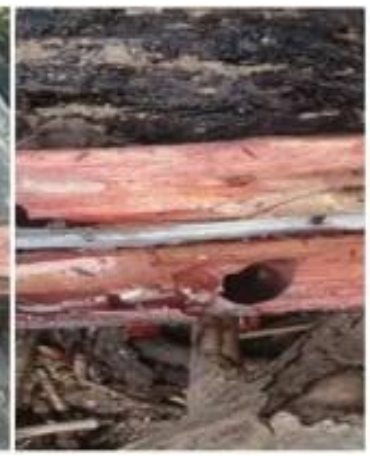

$\mathrm{C}$

Fig. 2. a) Rhizophora mucronata (Lamk.); b) Rhizophora apiculata; c) Rhizophora stylosa Griff

Roots and stems of mangrove wood have gaps or holes. This proves that the wood is occupied by Teredo Navalis L. One of the causes of wood damage is cellulose enzymes and high environmental temperatures. There fore the activity and spread of Teredo navalis $L$ is higher in the dry season [18].

\subsection{Dominance index analysis Teredo navalis $L$}

Based on the dominance index value at the root, it can be stated that the dominance of the species Teredo navalis $L$ at locations I and II is in the low category, as shown in the following table.

Table 2.Number of individuals and the dominance index Teredo navalis $L$ in the roots at locations I and II

\begin{tabular}{|c|l|c|c|c|c|c|}
\hline \multirow{2}{*}{$\begin{array}{c}\text { Area of } \\
\text { observat } \\
\text { ion }\end{array}$} & \multirow{2}{*}{ Mangrove type } & \multicolumn{2}{|c|}{$\begin{array}{c}\text { Number of } \\
\text { individuals }\end{array}$} & \multicolumn{2}{c|}{ Dominance index } & \multirow{2}{*}{$\begin{array}{c}\text { Categ } \\
\text { ory }\end{array}$} \\
\cline { 3 - 7 } & $\begin{array}{c}\text { Locatio } \\
\text { n I }\end{array}$ & $\begin{array}{c}\text { Location } \\
\text { II }\end{array}$ & $\begin{array}{c}\text { Locatio } \\
\text { n I }\end{array}$ & $\begin{array}{c}\text { Location } \\
\text { II }\end{array}$ & Low \\
\hline Roots & $\begin{array}{l}\text { Rhizophora } \\
\text { mucronata } \text { (Lamk.) }\end{array}$ & 33 & 26 & 0.12 & 0.20 & Low \\
\cline { 2 - 7 } & $\begin{array}{l}\text { Rhizophora } \\
\text { apiculata }\end{array}$ & 44 & 19 & 0.22 & 0.11 & Low \\
\cline { 2 - 6 } & $\begin{array}{l}\text { Rhizophora stylosa } \\
\text { Griff }\end{array}$ & 16 & 12 & 0.17 & 0.04 & \\
\hline
\end{tabular}

Based on table 2, the number of individuals Teredo navalis $L$ in location I was more than location II. Teredo navalis $L$ was found to occupy the roots of the species Rhizophora mucronata (Lamk.), Then the species Rhizophora apiculata. and at least Rhizophora stylosa Griff. Mean while, the dominance index value in the table above shows that the dominance of Teredo navalis $L$ is low because it tends to be close to 0 and there are no species that dominate the root habitat. If the organism lives in a habitat and is suitable for its environment, it will develop properly, and if There are differences in species composition in each mangrove because each species has a different adaptability in the roots [19]. If the dominance index value is high, then there are individuals who dominate, conversely if the dominance index value is low, there is no dominant individual. Mangrove ecosystems act as a productivity provider for abundant food for various types of marine animals [20] and provide a place for breeding, spawning and regeneration for aquatic biota 
[21]. The dominance index of Teredo navalis $L$ at the roots can be seen in the following graphic.

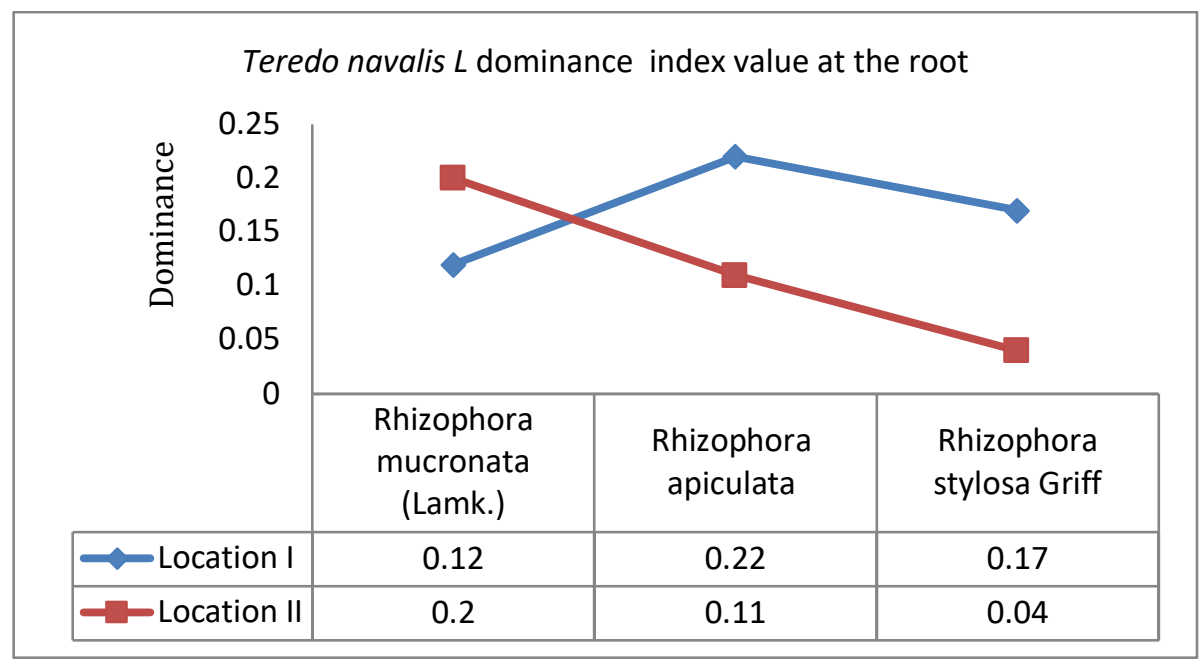

Fig. 3. Graph of dominance index Teredo navalis $L$ on the roots at locations I and II

Graph in Figure 3 shows that the dominance index value Teredo navalis $L$ in the roots is higher in the species. Rhizophora apiculata at location I with a value of 0.22 and the lowest in the species Rhizophora mucronata (Lamk.), namely 0.12 . where as at location II the dominance index Teredo navalis $L$ highest was found in Rhizophora mucronata (Lamk.), namely 0.2 and the lowest was Rhizophora stylosa Griff, which was 0.04. However, the dominance index value obtained at the roots at locations I and II is still in the low category. A low dominance index value indicates a low concentration and no species dominates its habitat [22]. Furthermore, the number of individuals and the dominance index Teredo navalis $L$ on the stem can be seen in Table 3 below.

Table 3. Number of individuals on the stem and dominance index of Teredo navalis $L$ at locations I and II

\begin{tabular}{|c|l|c|c|c|c|c|}
\hline \multirow{2}{*}{$\begin{array}{c}\text { Observa } \\
\text { tion } \\
\text { area }\end{array}$} & \multirow{2}{*}{ Mangrove type } & \multicolumn{2}{|c|}{$\begin{array}{c}\text { Number of } \\
\text { individuals }\end{array}$} & \multicolumn{2}{c|}{ Dominance index } & \multirow{2}{*}{$\begin{array}{c}\text { Categ } \\
\text { ory }\end{array}$} \\
\cline { 3 - 6 } & $\begin{array}{c}\text { Locatio } \\
\text { n I }\end{array}$ & $\begin{array}{c}\text { Locatio } \\
\text { n II }\end{array}$ & $\begin{array}{c}\text { Location } \\
\text { I }\end{array}$ & $\begin{array}{c}\text { Location } \\
\text { II }\end{array}$ & Low \\
\hline \multirow{2}{*}{ Stem } & $\begin{array}{l}\text { Rhizophora } \\
\text { mucronata } \text { (Lamk.) }\end{array}$ & 214 & 59 & 0.62 & 0.41 & Low \\
\cline { 2 - 6 } & $\begin{array}{l}\text { Rhizophora } \\
\text { apiculata }\end{array}$ & 55 & 32 & 0.04 & 0.12 & Low \\
\cline { 2 - 6 } & $\begin{array}{l}\text { Rhizophora stylosa } \\
\text { Griff }\end{array}$ & 31 & 21 & 0.01 & 0.05 & Low \\
\hline
\end{tabular}

Table 3 shows that the number of individuals Teredo navalis $L$ on the stem locations I and II were more abundant in the species Rhizophora mucronata (Lamk.) while less was found in the spesies Rhizophora stylosa Griff. Teredo navalis $L$ was found to mostly occupy the stem of Rhizophora mucronata (Lamk.). Then on the stem of Rhizophora apiculata and Rhizophora stylosa Griff. This will also illustrate the dominance index value of Teredo navalis $L$ as shown in the following graph. 


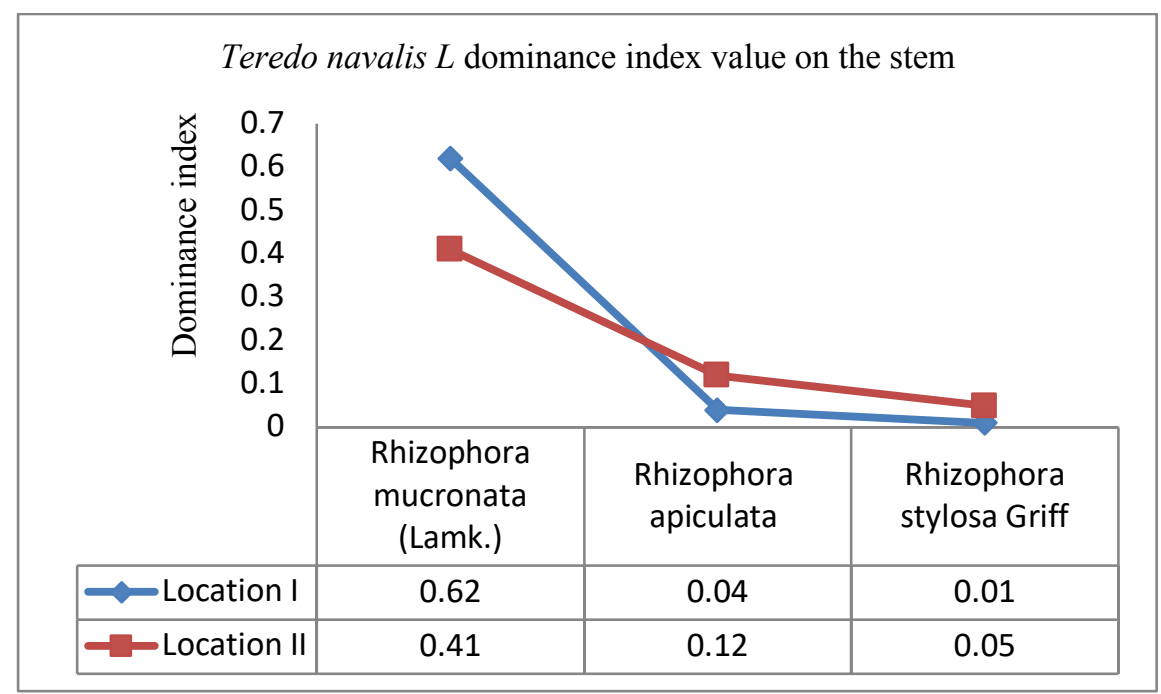

Fig. 4. Dominance index graph Teredo navalis $L$ on the stems at locations I and II

Based on the graph from Figure 4 above shows that the dominance index value Teredo navalis $L$ on the stems at locations I and II for the three types of mangroves are in the low category, with Each dominance index value is for location I the dominance index value for Rhizophora mucronata (Lamk.) $=0.62$, Rhizophora apiculata $=0.04$ and Rhizophora stylosa Griff $=0.01$. While the dominance index value at the second location is Rhizophora mucronata (Lamk.) is 0.41 , Rhizophora apiculata $=0.012$ and Rhizophora stylosa Griff $=$ 0.05 . This shows that from these two locations there is not species that dominates the other species so that the life of Teredo navalis $L$ is not stressed [23].

\subsection{Mangrove environmental management strategy in Wailukum}

Systematic identification of internal and external factors, the results of which will be used to formulate a mangrove ecosystem management strategy at the research location using the SWOT method. The position of the mangrove ecosystem management strategy in Wailukum is in the domain of WO strengths (weaknesses) and opportunities (quadrant IV), which can be seen in table 4 below. 


\section{ICENIS 2020}

Table 4. Internal and external factors for mangrove environmental management in Wailukum East

Halmahera Regency

\begin{tabular}{|c|c|c|c|c|}
\hline \multirow{2}{*}{ No } & Internal Factors & Value & External factors & Value \\
\hline & Strength (S) & & Opportunity (O) & \\
\hline 1 & $\begin{array}{l}\text { Wailukum mangrove area is a } \\
\text { protected forest }\end{array}$ & 1.5 & $\begin{array}{l}\text { Developed to become a } \\
\text { mangrove tourism spot }\end{array}$ & 0.5 \\
\hline 2 & $\begin{array}{l}\text { Local government } \\
\text { Reforestation of mangrove } \\
\text { areas and provide alternative } \\
\text { livelihoods for local } \\
\text { communities. }\end{array}$ & 1.4 & $\begin{array}{l}\text { Potential for mangrove } \\
\text { nurseries } \\
\text { Implementation of the } \\
\text { silvofishery system }\end{array}$ & $\begin{array}{l}1.5 \\
0.6\end{array}$ \\
\hline \multicolumn{2}{|r|}{ 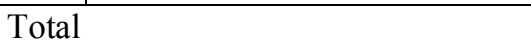 } & 2.9 & Total & 2.6 \\
\hline No & Weaknesses (W) & Value & Threats $(\mathrm{T})$ & Value \\
\hline 1 & $\begin{array}{l}\text { Lack of alternative } \\
\text { employment opportunities for } \\
\text { communities }\end{array}$ & 0.8 & $\begin{array}{l}\text { Uncontrolled conversion of } \\
\text { mangrove land }\end{array}$ & 0.5 \\
\hline 2 & $\begin{array}{l}\text { Low economic level of the } \\
\text { Wailukum Village }\end{array}$ & 0.9 & $\begin{array}{l}\text { Land conversion mangroves } \\
\text { for unplanned ponds }\end{array}$ & 0.6 \\
\hline 3 & $\begin{array}{l}\text { Weak supervision from the } \\
\text { local government on land use } \\
\text { and use }\end{array}$ & 1.4 & $\begin{array}{l}\text { Non-selective logging of } \\
\text { mangroves for household } \\
\text { needs }\end{array}$ & 0.5 \\
\hline 4 & $\begin{array}{l}\text { Weak mangrove management } \\
\text { institutions }\end{array}$ & 1.4 & & \\
\hline \multicolumn{2}{|c|}{ Total } & 4.5 & Total & 1.1 \\
\hline \multicolumn{2}{|c|}{$\begin{array}{l}\text { Difference of strengths and } \\
\text { weaknesses }\end{array}$} & -1.6 & $\begin{array}{l}\text { Difference of opportunities } \\
\text { and Threats }\end{array}$ & 1.5 \\
\hline
\end{tabular}


Table 4. SWOT analysis of environmental management strategies in Wailukum

\begin{tabular}{|c|c|c|}
\hline & Strengths (S) & Weaknesses (W) \\
\hline $\begin{array}{c}\text { Internal } \\
\text { and external factors }\end{array}$ & $\begin{array}{l}\text { 1. Wailukum mangrove } \\
\text { areas are protected forest } \\
\text { 2. Reforestation of mangrove } \\
\text { areas and provide } \\
\text { alternative livelihoods for } \\
\text { local communities. }\end{array}$ & $\begin{array}{l}\text { 1. Lack of alternative } \\
\text { employment } \\
\text { opportunities for the } \\
\text { community } \\
\text { 2. The low economic level of } \\
\text { the Wailukum Village } \\
\text { community } \\
\text { 3. Weak supervision from } \\
\text { the local government on } \\
\text { land use and } \\
\text { management } \\
\text { 4. Weak mangrove } \\
\text { management institutions }\end{array}$ \\
\hline Opportunities $(\mathrm{O})$ & $\mathrm{S}-\mathrm{O}$ & Strategy W-O Strategy \\
\hline $\begin{array}{l}\text { 1. Development ecotourism } \\
\text { in mangrove areas. }\end{array}$ & $\begin{array}{l}\text { 1. Protecting mangrove } \\
\text { areas as protected forests } \\
\text { to maintain } \\
\text { sustainability so that } \\
\text { they can be used as } \\
\text { tourist attractions ( } \mathrm{S} \text { 1; } \\
\text { O 1). } \\
\text { 2. Empowering the } \\
\text { community by forming a } \\
\text { working group in order } \\
\text { to provide mangrove } \\
\text { seedlings (S 2; O 2). } \\
\text { 3. Organizing socialization } \\
\text { and training of } \\
\text { silvofishery systems for } \\
\text { coastal village } \\
\text { communities for } \\
\text { rehabilitation of } \\
\text { mangrove areas (S 2; O } \\
\text { 3) }\end{array}$ & $\begin{array}{l}\text { Providing employment } \\
\text { opportunities for local } \\
\text { workers, and educating local } \\
\text { people to manage and utilize } \\
\text { mangrove areas through } \\
\text { skills training (W 1, 2; O 1, } \\
\text { 2). }\end{array}$ \\
\hline Threats $(\mathrm{T})$ & $\mathrm{S}-\mathrm{T}$ & Strategy W - T strategy \\
\hline $\begin{array}{l}\text { 1.Uncontrolled Of mangrove } \\
\text { land functions conversion. } \\
\text { mangrove land for } \\
\text { unplanned ponds. } \\
\text { 2. Non-selective felling of } \\
\text { mangrove wood for } \\
\text { household needs }\end{array}$ & $\begin{array}{l}\text { 1. Coordinating among } \\
\text { stakeholders to } \\
\text { determine the status of } \\
\text { mangrove areas and } \\
\text { management regulations, } \\
\text { increasing supervision in } \\
\text { enforcing the regulatory } \\
\text { system to impose } \\
\text { sanctions on perpetrators } \\
\text { of violations ( } 1,2 ; \mathrm{T} 1 \text {, } \\
2,3 \text { ) }\end{array}$ & $\begin{array}{l}\text { 1.Providing knowledge, } \\
\text { raising awareness and } \\
\text { establishing the legitimacy } \\
\text { of mangrove management } \\
\text { at the local community } \\
\text { level (W 1, 2; T 1). } \\
\text { 2.Increasing supervision of } \\
\text { pond activities and } \\
\text { logging in the mangrove } \\
\text { ecosystem (W 3; T 1, 2). } \\
\text { 3.Directing local } \\
\text { communities to use }\end{array}$ \\
\hline
\end{tabular}




\begin{tabular}{|l|l|l|}
\hline & & $\begin{array}{l}\text { kerosene stoves as an } \\
\text { alternative to reduce } \\
\text { firewood use (W 2; T 2). }\end{array}$ \\
\hline
\end{tabular}

Table 4 shows that the mangrove environmental management strategy in Wailukum, East Halmahera Regency, namely (1) opening up jobs for the community, organizing socialization and training of the silvofishery system for coastal village communities for the rehabilitation of mangrove areas (2) making regulations to control community-based mangrove use and monitoring mangrove management violations. In implementing this strategy, it needs to be aligned with continuous supervision and synergy by the Regional Government of East Halmahera Regency.

Mangrove forest management is an important part of environmental conservation efforts in coastal areas [24]. The causes of damage to mangrove areas, namely pollution, conversion of mangrove forests that ignore environmental factors and the high activity of tree cutting. Therefore, mangrove ecosystem management must involve the community in managing and conserving existing natural resources so that environmental management for sustainable development requires the concept of conservation and the role of the community [25]. Environmental management that is focused on the community is an environmental management mechanism by educating local people to be actively involved in the process of managing natural resources in the area [26].

\section{Conclusion}

The results of this study found that there are three types of mangroves that live in the medium tide zone, namely Rhizophora mucronata (Lamk.) Rhizophora apiculata and Rhizophora stylosa Griff. Characteristics of roots and stems have gaps and brittle easily. The dominance index of Teredo navalis $L$ on the roots and stems is in the low category with the index range 0.01-0.62. Strategies that need to be used for environmental management of mangroves in Wailukum, East Halmahera Regency, are to open employment opportunities for the community, organize socialization and training of silvofishery systems for workers, make regulations to control community-based mangrove use and monitor violations of mangrove management.

\section{Acknowledgments}

Author thanks the Chancellor through the leadership of LPPM Diponegoro University who has funded my Doctoral Dissertation Research with an SPK Number. 225-18 / UN7.6.1 / PP / 2020, and provide opportunities and facilities for researchers to complete this research. Researchers are also grateful to the Department of Marine Affairs and Fisheries, East Halmahera Regency, North Maluku Province for their assistance and cooperation so that this research activity can be carried out well. 


\section{Reference}

1. MM Islami, I. Yulia Ikhsani, T. Indrabudi, and IAH Pelupessy. Composition of Species, Diversity, and Utilization of Mollusks on the Coast of Saparua Island, Central Maluku. Widyariset Journal 4 (2), 173-188 (2018)

2. YI Ulumuddin1, A. Dwi Setyawan. Exploration of mangrove forests in the Tambelan and Serasan Islands: Composition of species, forest distribution maps, and potential threats. PROS SEM NAS MASY BIODIV INDON 3 (1), 45-55 (2017)

3. A. Khaery, C. Kusmana, and Y. Setiawan. Mangrove Ecosystem Management Strategy in Passare Apua Village, Lantari Jaya District, Bombana Regency, Southeast Sulawesi Province. Journal of Tropical Silviculture 7 (1), 38-44 (2016)

4. Hariphin, R. Linda, E. Rusmiyanto PW. Vegetation Analysis of Mangrove Forest in River Estuary Area Serukam, Bengkayang Regency. Protobiont 5 (3), 66-72 (2016)

5. A. Rakhfid and Rochmady. Analysis of the Economic Value of Mangrove Forests in Muna District (Case Study in Labone Village, Lasalepa District and Wabintingi Village, Lohia District). Scientific Journal of Agribusiness and Fisheries (Agrikan UMMU-Ternate) 6, 82-104 (2014)

6. NM Heriyanto \& E. Subiandono. The Role of Mangrove Biomass in Storing Karbondi Kubu Raya, West Kalimantan. Journal of Policy Analysis 13 (1), 1-12 (2016)

7. L. MS Borges, LM Merckelbach, Í.Sampalo, S. M.Cragg. Diversity, environmental requirements, and biogeography of bivalve wood-borers (Teredinidae) in European coastal waters. Frontiers in Zoology 11, 1-13. (2014).

8. AM Eriksen, DJ Gregory. C. Villa, N. Lynnerup, KB Botfeldtc, AR Rasmussen. The effects of wood anisotropy on the mode of attack by the wood borer Teredo navalis and the implications for underwater cultural heritage. International Biodeterioration \& Biodegradation 107, 117-122 (2016)

9. H. Maclntosh, R. De Nys and S. Whalan. Contrasting life histories in shipworms: Growth, reproductive development and fecundity. Journal of Experimental Marine Biology and Ecology 459, 80-86 (2014)

10. Y. Sinyo, S. Anggoro, TR Soeprobowati. Teredo Navalis L Grazing Activity in Mangrove Habitat Using Scan Sampling Method. Scientific Journal @ Mathematics and Natural Sciences Education 4 (2), 1-6 (2019).

11. N.Kariada TM and A. Irsadi. The Role of Mangroves as Water Pollution Biofilter in the Tapak Milkfish Pond Area, Semarang. Human and Environment Journal 21(2), 188-194 (2014)

12. D. Rachmawati, Setyobudiandi, Isdradjad, and H. Endang. Potential Estimation of Stored Carbon in Mangrove Vegetation in the Coastal Zone of Muara Gembong, Bekasi Regency. Omni-Aquatic Journal 13 (19), 85-91 (2014).

13. A. Irsadi, S. Anggoro, and TR Soeprobowat. Environmental Factors Supporting Mangrove Ecosystem in Semarang-Demak Coastal Area. E3S Web of Conferences 125, 1-5 (2019).

14. DWK Baderan, R. Utina \& N. Lapolo. Vegetation structure, species diversity, and mangrove zonation patterns in the Tanjung Panjang Nature Reserve Area, Gorontalo, Indonesia. International Journal of Applied Biology 2 (2), 1-12 (2018) 
15. Dien, HMA Rembet, JWNU Wantasen. A. Profile of Mangrove Ecosystem in BAHOI Village, North Minahasa Regency. Platax Scientific Journal 4 (1), 112-119 (2016).

16. A. Maulud, S. Purnawan, Nurfadillah. Abundance of Penempel Biota in Mangroves in Muara Alue Naga, Syiah Kuala District, Banda Aceh City. Unsyiah Marine and Fisheries Student Scientific Journal 2 (4), 490-496 (2017).

17. AM Eriksen, D. Gregory, K. The survival of Teredo navalis L. in timber wrapped in TERRAM 4000 and a plastic membrane, Int. Biodeterior. Biodegradation 86, 96-101 (2014).

18. SK Pati, MV Rao, M. Balaji, D. Swain. Deterioration of Wood by Marine Borers in a Tropical Harbor: Influence of Environmental Parameters and Biotic Factors. International Journal of Marine Science 4 (13), 119-133 (2014)

19. Hambran, R. Linda, I. Lovadi. Analysis of Mangrove Vegetation in Sebubus Village, Paloh District, Sambas Regency. Protobiont Journal 3 (2), 201-208 (2014).

20. NR Isnaningsih, and MP Patria. The Role of the Mollusca Community in Supporting the Function of the Mangrove Area in Tanjung Lesung, Pandeglang, Banten. Journal of Biotropics 6 (2), 35-44 (2018).

21. DA Candri, B. Junaedah, H. Ahyadi, Y. Zamroni. Diversity of Molluscs in Mangrove Ecosystems on the Island of Lombok. Bio Wallacea Scientific Journal of Biological Sciences 4 (2), 88-93 (2018).

22. DJ Prihadi, I. Riyantini and MR Ismail. Management of mangrove ecosystem conditions and environmental carrying capacity of mangrove marine tourism areas in Karangsong Indramayu. National marine journal 13 (1), 53-64 (2018).23. D. Swaim, AV. Pacllu and MV. Rao. Biodiversity of Shipworms (Mollusca: Bivalvia: Teredinidae) in the Vicinity of a Tropical Mangrove Ecosystem along Bay of Bengal, Andhra Pradesh, India 20, 1-5 (2017).

24. B. Utomo, S. Budiastuti, C. Muryani. Mangrove Forest Management Strategy in Tanggul Tlare Village, Kedung District, Jepara Regency. Journal of Environmental Science 15 (2), 117-123 (2017).

25. AS Sinery, J. Manusawai. Community Participation in the Wosi Rendani Protection Forest Management Program. Journal of Humans and Environment, 23 (3), 394-401 (2016).

26. Suryadi1, Aipassa, Ruchaemi \& Matius. Study of the Use of the Bukit Soeharto Forest Park Area. Dipterocarp Ecosystem Research Journal 3 (1), $43-48$ (2017). 